\title{
Primary mitral regurgitation - etiopathogenesis and echocardiographic evaluation
}

\author{
(D)Sandra Makarović* \\ University Hospital Centre \\ Osijek, Osijek, Croatia
}

KEYWORDS: echocardiography, mitral regurgitation, mitral valve surgery.
CITATION: Cardiol Croat. 2021;16(9-10):311. | https://doi.org/10.15836/ccar2021.311

*ADDRESS FOR CORRESPONDENCE: Sandra Makarović, Klinički bolnički centar Osijek, J. Huttlera 4, HR-31000 Osijek, Croatia. / Phone: +385-91-591-6875 / E-mail: smakarovic36@gmail.com

ORCID: Sandra Makarović, https://orcid.org/0000-0002-7487-1189

\section{RECEIVED:}

July 31, 2021

ACCEPTED:

August 5, 2021

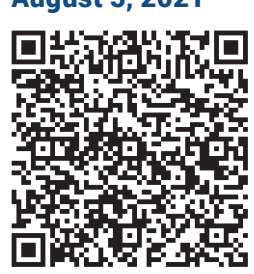

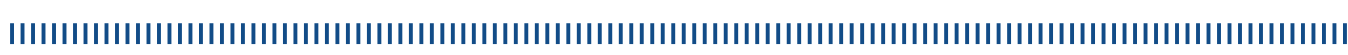

Mitral regurgitation is a common but complex valvular heart disease. Severe mitral regurgitation can produce left ventricular remodeling and finally irreversible left ventricular dysfunction. Echocardiography allows the reliable identification of the presence, severity, etiology, and mechanisms as well as the pathologic lesions of mitral regurgitation. The following questions relating to echocardiography should be asked before patients undergo surgery: (1) Is the mitral regurgitation organic or functional? (2) When is the optimal time for surgery? (3) What is the etiology of mitral regurgitation? (4) Where is the lesion(s)? (5) Can the mitral valve be repaired? (6) Which surgical technique is most appropriate? Quantitative assessment of the severity of mitral regurgitation is essential for the optimal timing of surgery. Transesophageal echocardiography as well as three-dimensional echocardiography can help to identify the etiology, mechanisms, and pathologic lesions prior to possible mitral valve repair. The optimal timing of mitral valve surgery in patients with severe mitral regurgitation is crucial. In recent years, mitral valve repair has been shown to be better than mitral valve replacement for both shortand long-term outcome. Important issues such as reducing operative mortality, improving long-term survival, and improving the rate of mitral valve repair are crucial when considering mitral valve surgery. ${ }^{1,2}$

LITERATURE IIIIIIIIIIIIIIIIIIIIIIIIIIIIIIIIIIIIIIIIIIIIIIIIIIIIIIIIIIIIIIIIIIIIIIIIIIIIIIIIIIIIIIIIIIIIIIIIIIIIII

1. Fu M, Chua S, Chang JP. Nonischemic Severe Mitral Regurgitation: When and How to Operate? The Role of Echocardiography. J Med Ultrasound. 2008:16(2):87-100. https://doi.org/10.1016/S0929-6441(08)60010-7

2. Baumgartner H, Falk V, Bax JJ, De Bonis M, Hamm C, Holm PJ, et al; ESC Scientific Document Group. 2017 ESC/EACTS Guidelines for the management of valvular heart disease. Eur Heart J. 2017 Sep 21;38(36):2739-2791. https://doi.org/10.1093/eurheartj/ehx391 